\title{
Code Mixing Employed by the English Lecturers in EFL Classroom
}

\author{
Asep Hardiyanto ${ }^{\mathbf{1}}$, and Alis Setiani \\ asephardian005@gmail.com \\ Program Studi Pendidikan Bahasa Inggris STKIP Muhammadiyah Kotabumi
}

\begin{abstract}
The purpose of this research is to investigate the forms and factors influencing code mixing produced by lecturers. The data of this research is lecturers' utterances during the subject of speaking and writing learning process in English education study program of STKIP Muhammadiyah Kotabumi. This research used descriptive qualitative method by sociolinguistic approach. The data of this research were recorded, analyzed, and interpreted descriptively. The research result showed that (1) There are four forms of code mixing found such as word, phrase, clause, and repetition word; (2) There are three factors influencing code mixing occurences such as identification of roles, variance identification, and limitation of language utterance. Furthermore, this article is expected to contribute the knowledge related code mixing studies for further research.
\end{abstract}

Key words : code mixing, occurences, forms, and factors.

\section{INTRODUCTION}

Language is primary tool for human to communicate with others. It is acknowledged that language is a system of pronounced sounds which is used by people as the tool of making relationship among people in the world especially in their social life. In society, language is used to convey messages, both of speakers to the listeners, and the writers to the readers. According to Sumarsono (2014), "language is considered as the product of social or cultural, even an indispensable part of the culture". From this statement, it is obvious that there is a relationship between language and social life. This relation is called by sociolinguistic. Sociolinguistic is a study of phenomenon of language in society.

People speak based on where they come from and/or their environment. When people involved in certain conversation they tend to use the language they had. Generally, people often use more than one language then the one who master more than one language or which is called by bilingual or multilingual. In bilingual and multilingual societies, people may produce some certain codes. For instance, when people master more than one 
languages they will have tendency to mix their language in daily conversation. They will mix it from one into others.

However, English is one of International language used in Indonesia and it has a great influence especially in English learning process such as listening, reading, speaking, and writing. English skills have the important roles to develop students' ability in compreheding English as foreign language (EFL). As the result, the lecturer who teach English subject should be able to comprehend two languages both National and International language. Language depency in multilingual society is called code mixing in Rokhman (2013).

Furthermore, Code mixing can be see in both written and spoken language. Code mixing in written language can be found in such printed mass media. Meanwhile, code mixing in spoken language usually recognized in several occasions. In the context of teaching learning process, the phenomenon of code mixing mostly happened in English skill subjects. Nowadays, English lecturer especially for speaking and writing subjects should at least use bilingual to cover or to give models for the students in using the language. Bilingual here means that the lecturer mix English and Bahasa in formal classroom.
Then, the study about code mixing have been investigated by Sumarsih et al. (2014), Sutinawati et al. (2014), and Ayeomoni (2006). From this previous research, it can be stated that the phenomena of code mixing happened in the society especially those who use bilingual or multilingual. Finally, Having reviewed some previous related research above, however, the phenomenon of code mixing in formal setting especially the code mixing encountered by the English lecturer in speaking and writing subjects have not been explored yet.

Meanwhile, phenomena is important to be investigated due to several reasons. First, lecturers are bilingual and multilingual. Second, realize the importance of languages so that the existence of language will be increase. Therefore, the research formulates the research questions and research objectives as follows

\section{Research Questions:}

1. What are the forms of code mixing employed by the lecturers of speaking and writing subjects in the fifth semester?

2. What are factors influencing code mixing employed by the lecturers of speaking and writing subjects in the fifth semester? 


\section{Research Objectives:}

1. To find out the forms of code mixing employed by the lecturers of speaking and writing subjects in the fifth semester

2. To describe the factors influencing code mixing employed by the lecturers of speaking and writing subjects in the fifth semester

\section{LITERATURE REVIEW}

\section{A. Sociolinguistics}

The study about the relation of language and society is called sociolingistic. According to Holmes (2013), sociolinguistic means a study relationship between language and society which explains the different speech of people when they are in different social context and identify the social functions of language to convey meaning of communication. Sociolinguistics is a very broad field, and it can be used to describe many different ways of studying language (Meyerhoff, 2006). That means sociolinguistics is study about relation between language and society in different social context of communication.

\section{B. Bilingualism}

When two ore more languages used in communication by the same speakers, it can be said that those languages contact each other. Events the speakers used two or more languages it is called bilingualism.
People who comprehend bilingualism is called bilingual. Weinreich in Tarigan (2009) informed that in communication with other people bilingual mean can used two languages in change. Some bilingual speakers are accustomed to using only one language with a person to communication. That situation requires the use of a specific language for different people and situation. People use more than one language depend on sosial context, which is a situation where they learn first and second languages in communities.

In addition, Ann in Lucas (2004) if a speaker declared itself bilingual to other people, this would not necessarily mean that every person is bilingual. In fact it is often the case that such a society has a bilingual language policy although many or most of its speakers are monolingual. Thus, that not all person in the society is bilingual because its only as policy in society.

\section{Code Mixing}

Everybody must have a basic ability of communication, which call it as communicative competence.

Communicative competence refers to knowing when to speak, when not to, and what to talk, with whom, when, where, and in what manner. In a word communicative competence is related to language and language use. Consequently, human's 
view of the world depends on the particular language they have learned. Thus, the phenomenon of bilingualism result in the occurance is code mixing. These phonomenon happens not only between indigenous language and Indonesian, but also among indigenous language, Indonesian, and English. The phonomenon of code mixing does not only occur in daily life situation.

Additionally, Ohoiwutun (2007:69) explained that phenomenon of code mixing is something which often happened in communication activity, not only in bilingual society, but also in multilingual. Being able to mix this code : (1) insertion of word, (2) insertion of phrase, (3) insertion of clause, (4) insertion of hyrid, (5) insertion of idiom, (6) insertion of repetition word. Furthermore, factors influencing code mixing include: (1) identification of roles, (2) variance identification, (3) feeling to explain and interpretation (Suwito in Rulyandi, 2014), (4) unformal language situation, factors, and (5) limitation of language utterance (Sutinawati et al., 2014).

\section{RESEARCH METHOD}

The design of method used in this research is descriptive qualitative method descriptive qualitative method and the data came from the records of lecturers utterances. The subjects of this research are lecturers of speaking and writing subject in the fifth semester of STKIP Muhammadiyah Kotabumi. This research was analyzed based on the theory of Suwito in Fitriyanti (2015) classified code mixing into six forms according to linguistic elements that involved in code mixing, those are, the insertion in form of words, phrases, hybrid, repetition words, idioms, and clauses.

The data collect of this research used video record to record to get the forms of code mixing, interview to get the factors influencing code mixing, in addition the researchers also used data card to note forms of code mixing.

The data analysis, the researchers used triangulation with steps. Firsly, the researchers reduce the data from video transcription. Secondly, the data was reduced classified into forms of code mixing and take in data card. The last step, the researchers make verification conclusion.

\section{RESULT AND DISCUSSIONS}

Based on the analysis, the researchers found several tpyes of code mixing employed by the English lecturers in speaking and writing subjects such as word, phrase, clause, and repetition word. Further, the finding shows that there are 19 occurances code mixing in speaking subject which consist of words $73.7 \%$, 
phrases $5.3 \%$, clauses $15.7 \%$ and the last repetitions word $5.3 \%$. In another hand, there were 76 occurances in writing subject, with classification words $89.5 \%$, phrases $2.7 \%$, clauses $6.5 \%$, and repetition word $1.3 \%$. In the following section, the examples are displayed

\section{Word}

a. speaking subject

- This is good issue because you also can be the team successing of the Bupati

- I would like not kastil,

b. writing subjet

- Ok I wanna ask you about problem, solution, $\underline{\mathrm{udah}}$

- What is nambah in English?

Phrase

a. speaking subject

- This the topic to discuss in seminar neo communism in Indonesia and the presenter is Sigit Suharjono mantan $\underline{\text { komunis }}$

b. writing subjet

- Heni Rohaina satu kelompok, Reni and Espi Ersela

\section{Clause}

a. speaking subject

- This is change, dimana kamu melaporkan Sentral

- Saya berharap final project the movie will be much better

b. writing subjet

- Come on I invite you to present about your problem, solution satu mahasiswa buruan
- Coba kalian keluar and I want call one by one and the problem is not one maybe there are many problem but you can choose the best one

Repetition word

a. speaking subject

- Who are the interview expected, emak emak?

b. writing subjet

- One, two, three, four, five, six, seven, eight, nine, ten ujung-ujung yeah ok Devi

Thus, in the two English subjects, the most types of code mixing found is the word level. Later, in the second position is occupied by clause level. Then, the third is at the level of phrase and repetition word. It means that lecturers always mixed a few words or sentences of Bahasa in their utterances so that learning materials can be understood by the students.

Moreover, based on the discussion above, this finding of factors influencing code mixing supported by the theory from Suwito such identification of role and variance identification and theory from Sutinawati et al. limitation language utterance. It can be concluded that there are three factors influencing of code mixing made the learning process more suitable and easily achieved the goal of learning process. 


\section{CONCLUSION AND SUGGESTION}

From the results and discussion above, it can be summarized that there are four forms of code mixing found in this research-words, phrases, clauses, and repetition words. Furthermore, there are three factors influencing of code mixing employed by the English lecturers. First, identification of; second, variance identification;the last, limitation of language utterances caused by the students.

Besides, from this study it is suggested that for the further reasearchers who want to investigate similar topics, they should give an illustration of the languages used in the real condition around them especially sociolinguistic study. In the future, another study concerning about code mixing or another aspect related to the sociolinguistic will be useful.

\section{REFERENCES}

Fitriyanti, Lisa. 2015. The Analysis of Indonesian-English Code Mixing Used in "Manusia Setengah Salmon" Novel By Raditya Dika. Thesis is not publised. Kotabumi: STKIP Muhammadiyah Kotabumi.

Holmes, Janet. 2013. An Introduction to Sociolinguistics. New York: Routledge.

Lucas, Ceil (Ed). 2004. The Sociolinguistics of Sign Languages. United Kingdom: Cambridge University Press.
Meyerhoff, Mirriam. 2006. Introducing Sociolinguistics. New York: Routledge.

Ohoiwutun, Paul. 2007. Sosiolinguistik: Memahami Bahasa dalam Konteks Masyarakat dan Kebudayaan. Jakarta: Kesaint Blanc.

Rokhman, Fathur. 2013. Sosiolinguistik: Suatu Pendekatan Pembelajaran Bahasa dalam Masyarakat Multikultural. Yogyakarta: Graha Ilmu

Rulyandi, Muhammad Rohmadi, \& Edy Tri Sulistyo. 2014. Alih Kode dan Campur Kode dalam Pembelajaran Bahasa Indonesia di SMA. In Journal of Paedagogia. (Daring). Vol. 17 (1): 27-39. Retrieved from: www.jurnal.fkip.uns.ac.id/. December 2016)

Sumarsih et al. 2014. Code Switching and Code Mixing in Indonesia: Study in Sociolinguistics.In Journal English Language and Literature Studies. (Daring). Vol.4(1):7792. Retrieved from: http://www.ccsenet.org/ (3 November 2016)

Sumarsono.

2014.

Sosiolinguistik.Yogyakarta:

Pustaka Belajar.

Sutinawati, Rusdhianti Wuryaningrum, \& Anita Widjajanti. 2014. Code Switching and Code Mixing in Oral Communication of UKM Tiang Theatre's Members, the Faculty of Teacher Training and Educational Jember University. (Daring). Retrieved from: repository.unej.ac.id (10 November 2016)

Tarigan, Henry Guntur. 2009. Pengajaran Kedwibahasaan. Bandung: Angkas 